\title{
PENGEMBANGAN PRODUKSI MINUMAN RUMPUT LAUT Euchema cottonii DI KELURAHAN MALALAYANG DUA KECAMATAN MALALAYANG, KOTA MANADO
}

\author{
Grace Sanger G. ${ }^{1}$, Yan R. Assa ${ }^{2}$ \\ 1) Staf pengajar pada Program Studi Teknologi Hasil Perikanan FPIK Unsrat Manado, 95115. \\ 2) Staf pengajar pada Program Studi Ilmu dan Teknologi Pangan Faperta Unsrat Manado, 95115 \\ Email: sanger.grace@yahoo.co.id
}

\begin{abstract}
ABSTRAK
Sasaran program ini berlokasi di Kelurahan Malalayang Dua Kecamatan Malalayang Kota Manado, yang secara geografis sangat strategis untuk dikembangkan industri pengolahan minuman rumput laut. Kelurahan ini merupakan daerah wisata kuliner, dimana terdapat banyak pengusaha makanan dan minuman. Sulawesi Utara, merupakan penghasil rumput laut yang besar, dengan demikian ketersediaan bahan baku mudah diperoleh dan memadai untuk pengolahan secara industri. Pengolahan minuman rumput laut yang terdiri dari sirup, sari dan serbuk instan, sangat mudah serta pemasarannya tidak sukar, dapat dijangkau oleh masyarakat kelas ekonomi atas maupun bawah. Tujuan program ini yaitu pengembangan lapangan usaha baru untuk meningkatkan ekonomi masyarakat serta meningkatkan nilai jual dan ekonomi rumput laut. Target khusus program IbM ini yaitu 1. Memproduksi minuman rumput laut memenuhi syarat sanitasi dan higienis, dikemas dan dilabel dengan baik/menarik; 2. Mengembangkan usaha industri minuman sirup rumput laut. Adapun metode pelaksanaan yang disepakati dengan mitra yaitu: 1. Masalah produksi minuman sirup rumput laut, pemasaran produk dan keuangan; 2. Metode untuk menyelesaikan masalah dengan penyuluhan, pelatihan, pendampingan dan evaluasi; 3. Prosedur kerja untuk menyelesaikan masalah melalui survei, penyuluhan, pelatihan, pendampingan, evaluasi, pelaporan dan jurnal.
\end{abstract}

Kata kunci: Euchema cottonii, Sirup, Industri Pengolahan.

\section{PENDAHULUAN}

Saat ini kebanyakan makanan siap konsumsi yang dijual di supermarket adalah minuman berasal dari buah-buah, tetapi minuman dari rumput laut jarang ditemui di lingkungan masyarakat (Wibowo dan Fitriani, 2012). Hal ini disebabkan karena banyak masyarakat belum menyadari manfaat rumput laut untuk kesehatan, sehingga pemanfaatannya hanya skala terbatas. Oleh karena itu perlu usaha untuk mendorong pengembangan produk pengolahan pada masyarakat untuk memberikan nilai tambah rumput laut yang kemudian dapat ditingkatkan menjadi skala industri untuk meningkatkan kesejahteraan masyarakat

Rumput laut (Euchema Sp.) merupakan salah satu sumber daya alam hayati Indonesia, yang mempunyai nilai ekonomis penting dalam industri kosmetik, pangan dan kesehatan. Rumput laut banyak diolah dalam bentuk kering setelah melalui proses penjemuran atau menjadi makanan siap konsumsi, seperti dodol, manisan, selai, kerupuk dan minuman yang sudah dikenal masyarakat Indonesia (Murdinah, 20013). Rumput laut bermanfaat sebagai antioksidan, anti peradangan, anti diabetes dan anti kanker (Sanger et al., 2013).

Keunggulan rumput laut ditinjau dari segi proses pengolahannya sangat mudah dan sederhana dapat dilakukan dalam skala rumah tangga. Keunggulan dari ketersediaan bahan baku yaitu mudah diperoleh dalam kuantitas cukup besar sehingga pengadaannya tidak ada masalah. (Anggadiredja, 2006).

Sirup umumnya berupa larutan kental yang mengandung gula minimum $55 \%$. Menurut Standar Industri Indonesia (SII) ada tiga kelompok kualitas sirup berdasarkan kadar gula dalam sirup. Sirup kualitas 1 mengandung kadar gula minimum $65 \%$, Sirup kualitas 2 mengandung kadar gula sekitar $60-65 \%$ dan sirup kualitas 3 mengandung kadar gula $55-60 \%$ (Suparapti, 2005).

Sirup rumput laut dibuat dari campuran ekstrak rumput laut ditambah dengan larutan gula dengan konsentrasi yang cukup tinggi, yang saat dikonsumsi harus diencerkan/ ditambah dengan air. Dari pengamatan mutu cemaran mikroba produk sirup tidak sebesar produk manisan basah. Hal ini karena proses pembuatan sirup rumput laut, bahan baku mengalami proses 
pemanasan yang dapat mematikan mikroba.(Murdinah, 2013).

Sasaran program ini untuk pengembangan produksi sirup rumput laut Euchema cootonii di Sulawesi Utara dengan mitra kelompok pengusaha makanan/minuman di Kelurahan Malalayang Dua Kecamatan Malalayang, Kegiatan dilakukan MaretNovember 2017. Untuk usaha pengembangan produksi minuman ataupun makanan di Kelurahan Malalayang ditemukan beberapa masalah seperti: 1. Aspek produksi: masyarakat belum mengetahui cara penanganan, pengolahan serta penjualan makanan yang sesuai standar sanitasi dan higienis. Masyarakat belum mengetahui manfaat rumput laut untuk kesehatan, penanganan rumput laut segar dan pengolahan rumput laut menjadi bahan makanan. 2. Aspek pemasaran: olahan minuman sirup rumput laut belum banyak dikenal oleh masyarakat, sehingga mungkin akan menyulitkan dalam pemasaran. 3. Aspek keuangan: ketidakmampuan pengusaha kecil untuk menyediakan modal biaya produksi, seperti pembelian alat-alat produksi.

Permasalahan lain dalam pengolahan makanan yaitu kurangnya penerapan sanitasi dan higienis dalam bahan baku, pengolahan, penyimpanan dan transportasi. Sanitasi dan higienis merupakan keadaan yang mencerminkan mengenai kebersihan dan kesehatan. Yang juga menjadi persyaratan untuk menghasilkan produk yang aman. Untuk menjaga sanitasi yang baik, maka pencucian adalah satu hal yang sangat penting untuk mencegah kontaminasi silang pada produk perikanan yang dihasilkan.

\section{METODE PENELITIAN}

Berdasarkan permasalahan masyarakat di Kelurahan Malalayang Dua maka diperlukan penyuluhan, pelatihan dan pendampingan akan aspek pangan dan kesehatan, nilai gizi rumput laut, pengolahan sirup rumput laut serta aspek produksi dan pemasaran. Sasaran penyuluhan dan pelatihan ada 2 kelompok Mitra yang disepakati bersama dengan anggota masingmasing Mitra sebanyak 10-15 orang.

Penyuluhan tentang nilai gizi rumput laut dan manfaatnya terhadap kesehatan, cara mengolah bahan makanan yang memenuhi syarat sanitasi dan higienis. Penyuluhan dan pelatihan tentang cara pembuatan rumput laut meliputi penanganan rumput laut yang baik untuk diolah menjadi bahan dasar produk makanan, pembuatan sirup rumput laut meliputi bahanbahan yang diperlukan, cara pengolahan, cara pengemasan dan penyimpanan.

Pelatihan aspek pemasaran yaitu: cara mempromosikan produk sirup rumput laut pada bazaar atau pameran sehingga produk dikenal luas. Pemasaran dapat dilakukan melalui departemen store/swalayan di Manado dan sekitarnya.

Pelatihan aspek keuangan: melatih perhitungan secara sederhana investasi (biaya tetap) pembuatan sirup rumput laut dan biaya operasional meliputi: pembelian bahan baku, peralatan dan upah tenaga kerja. Untuk pengembangan usaha, menjelaskan prosedur kredit dengan pihak BRI. Diharapkan dari pelatihan ini mitra dapat menghitung kebutuhan dana investasi, modal kerja untuk proposal kredit KUK di Bank BRI.

Pendampingan dilakukan pada Mitra pada saat produksi dan perhitungan biaya investasi. Evaluasi akan dilakukan dengan membagikan cek list proses pengolahan apakah sesuai sanitasi dan higienis dan manfaat penyuluhan dan pelatihan ini. Bagaimana tingkat kesukaan masyarakat dalam mengkonsumsi sirup ini yang sangat mempengaruhi tingkat pemasaran.

\section{HASIL DAN PEMBAHASAN}

Kelurahan ini mempunyai tempat usaha pengumpulan rumput laut dari berbagai daerah di Sulawesi Utara. Pengembangan industri makanan /minuman rumput laut dapat dilakukan karena ketersediaan rumput laut sangat berlimpah, selain dijual untuk daerah-daerah lain di Indonesia, rumput laut ini diekspor ke luar negeri secara kontinyu.

Pelaksanaan IbM dilaksanakan meliputi: penyuluhan, pelatihan, pendampingan dan evaluasi dengan capaian-capaian yang dihasilkan sebagai berikut:

\section{A. Penyuluhan}

Masyarakat dapat mengerti pentingnya memelihara sanitasi lingkungan, pentingnya sumber air yang bersih dan memadai. Peserta dapat mengetahui tentang sanitasi dan higienis bahan makanan mulai dari penyediaan bahan baku, penanganan dan pengolahan, pengemasan, penyimpanan dan distribusi dan pemasaran. Peserta dapat mengetahui bagaimana prospek pemasaran produk olahan bahan makanan untuk 
meningkatkan nilai tambah ekonomi keluarga. Peserta dapat mengerti tentang analisa keuangan untuk mengembangkan usaha yang meliputi biaya investasi, biaya tetap, biaya variabel, laba dan rugi. Serta bagaimana cara mengembangkan usaha menjadi skala yang lebih besar, sehingga dapat meningkatkan pendapatan dan membuka lapangan kerja baru.

\section{Pelatihan}

Peserta dapat mempersiapkan rumput laut kering untuk dijadikan bahan baku olahan bahan makanan dan minuman yang putih bersih. Untuk menghilangkan bau rumput laut yang telah putih bersih disiram dengan jeruk kemudian dibiarkan 15 menit setelah itu dibilas dengan air masak. Ibu-ibu dapat membuat sendiri sirup rumput laut dengan menggunakan bahan-bahan tambahan seperti gula, jeruk nipis, nanas, papaya. Yang didahului dengan peragaan cara membuat sirup yang saniter dan higienis. Ibu-ibu dapat menilai secara organoleptik kwalitas sirup rumput laut. Sirup yang sudah selesai dituang dalam tekoh. Kemudian sirup dimasukkan dalam gelas-gelas kecil untuk dicicipi. Ibu-ibu diberikan check list untuk memberikan penilaian tentang tingkat kesukaan dengan nilai $1-9$. Penilaian terhadap bau, rasa, warna dan kekentalan. Ibu-ibu dapat mengetahui cara mengemas bahan makanan yang baik. Cara pengemasan yang baik dijelaskan meliputi: wadah harus bersih, harus tertutup rapat, sehingga menjamin produk itu bersih dan sehat.

\section{Pelatihan aspek pemasaran.}

Peserta mengetahui cara mempromosikan produk, misalnya dengan mengajak mencicipi dan memberikan penyajian yang menarik, dilaksanakan pada bazaar atau pameran sehingga produk dikenal luas. Pemasaran dapat dilakukan melalui departemen store/swalayan di Manado dan sekitarnya. dan untuk memperlancar penjualan untuk menarik konsumen diberi label yang baik dan menarik. Produk diberi nama misalnya: minuman sirup rumput laut "Malalayang Dua" sebagai sumber serat dan antioksidan. Disarankan untuk menjamin rasa aman dan kepercayaan konsumen minuman sirup mempunyai komposisi kandungan gizi, batas kadaluwarsa dan dilengkapi dengan izin BPOM.

\section{Pelatihan dan pendampingan analisa aspek keuangan.}

Peserta dapat melakukan perhitungan secara sederhana investasi (biaya tetap) pembuatan sirup rumput laut dan biaya operasional meliputi: pembelian bahan baku, peralatan dan upah tenaga kerja. Untuk pengembangan usaha, menjelaskan prosedur kredit dengan pihak BRI.

\section{KESIMPULAN}

Masyarakat berkemauan untuk membuka usaha minuman rumput laut dengan cita rasa yang khas dan disukai konsumen, dengan menggunakan kemasan yang baik dapat diharapkan mampu menarik minat masyarakat untuk mengkonsumsinya sebagai minuman yang bermanfaat untuk kesehatan. Pemasaran produk akan makin luas apabila produk tersebut bermutu tinggi, dikemas dengan memiliki informasi nilai gizi dan izin departemen Kesehatan/BPOM dapat meningkatkan daya jual serta dapat meningkatkan lapangan usaha baru melalui pengembangan usaha menjadi skala industry sirup rumput laut.

\section{DAFTAR PUSTAKA}

Anggadiredja, J., Irawati, S. dan Kusmiyati. 2006. Algae: Pembudidayaan, Pengolahan, dan Pemasaran Komoditas perikanan Potensial, Jakarta: Penebar Swadaya.

Murdinah. 2013. Kajian Mutu Produk Aneka Olahan Rumput Laut Euchema cottonii. Prosiding Perencanaan Bulan Mutu Dan Keamanan Hasil Perikanan \& Seminar Nasional Masyarakat Pengolahan Hasil Perikanan (MPHPI) Ke-V/18-19 Oktober 2013. Universitas Diponegoro.

Sanger G. 2009. Mutu Permen Rumput Laut (Eucheuma cottonii). Pacific Journal. Regional Board Of Research North Sulawesi Vol.2 No.3. ISSN 1907-9672. Hal 374-376.

Sanger G. 2010. Kandungan Fosfor Minuman Sari Rumput Laut (Euchema cottonii) (Pacific Journal Regional Board of Research vol.1 No.5. ISSN 1907-9672. Hal 792-795.

Sanger G. Widjanarko, S.B., Kusnadi, J. and Berhimpon S. 2013 Antioxidant Activity of Methanol Extract of Seaweeds Obtained from North Sulawesi. 2013. Food Science and Quality Management. Vol. 19. ISSN 22246088 (Paper).

Suprapti L. 2005. Membuat aneka Olahan Nanas. Puspa Swara Indonesia

Wibowo L. dan Fitriyani. 2012. Pengolahan Rumput Laut (Euchema cootonii) Menjadi Serbuk Minuman Instant. Jurusan Ilmu Kelautan dan Perikanan, Politeknik Negeri Pontianak). 8(2). ISSN 1693-9085101-109 hal. 